DOI: $10.19195 / 0137-1134.114 .38$

\author{
RAJMUND MOLSKI \\ Uniwersytet Szczeciński \\ rajmund.molski@usz.edu.pl
}

\title{
O SYMBIOZIE PRAWA ANTYMONOPOLOWEGO I DEMOKRACJI
}

\begin{abstract}
W demokratycznym społeczeństwie dwóch granic nie wolno przekraczać nigdy: pierwszej — poza którą rodzi się nielegitymowana władza prywatna, i drugiej — poza którą legitymowana władza publiczna przeradza się we władzę nielegitymowaną ${ }^{1}$.
\end{abstract}

\begin{abstract}
Abstrakt: Wielowymiarowe i wielokierunkowe relacje między prawem antymonopolowym a demokracją bywają niejednokrotnie zawiłe i ambiwalentne. Niektóre z nich mają charakter pozytywny (pozytywne korelacje), a inne - negatywny (kontradykcje). Niniejsze opracowanie poświęcone jest niektórym spośród tych pierwszych powiązań, które szczególnie absorbują uwagę teoretyków i praktyków państwa i prawa. Celem opracowania jest raczej próba podsycenia inspiracji do przemyśleń na temat tytułowego zagadnienia aniżeli prowokowanie akceptacji lub sprzeciwu w tej kwestii. Niemniej jednak w opinii autora dostatecznie wiele argumentów przemawia za tezą, że między prawem antymonopolowym a demokracją istnieje wyraźna symbioza (jeśli nie synergia).
\end{abstract}

Słowa kluczowe: prawo antymonopolowe, demokracja, pozytywne korelacje

Z pozoru relacje między prawem antymonopolowym a demokracją wydają się nieskomplikowane, skoro funkcjonuje ono częściej w krajach demokratycznych i wolnorynkowych niż autorytarnych i etatystycznych ${ }^{2}$. Ten pozytywny związek maskuje jednak zawiłe i niejednokrotnie ambiwalentne, wielowymiarowe i wielokierunkowe powiązania między tymi kategoriami, implikowane w szczególności miriadami reperkusji interwencji antymonopolowych dla demokracji. Ramy niniejszego opracowania nie pozwalają na całościowe i wyczerpujące ujęcie tej niezwykle

${ }^{1}$ G. Amato, Antitrust Law and the Bounds of Power: The Dilemma of Liberal Democracy in the History of the Market, Oxford 1997, s. 3.

2 R. Prakkal, E.E. Laine, Capitalism, antitrust, and democracy: Perfect partners or strange bedfellows?, „The Antitrust Bulletin” 61, 2016, nr 2, s. 231. 
rozległej i złożonej problematyki. Ogranicza się ono zatem jedynie do naświetlenia niektórych pozytywnych korelacji między prawem antymonopolowym a demokracją, które szczególnie absorbują uwagę teoretyków i praktyków państwa i prawa. Problematyka negatywnych korelacji (kontradykcji) między tymi kategoriami wymagałaby już odrębnego opracowania. Wypada też zaznaczyć, że prezentowane dominujące $\mathrm{w}$ dyskursie naukowym poglądy w kwestii pozytywnych korelacji między prawem antymonopolowym a demokracją zasługują na uwagę nie tyle ze względu na akceptację lub sprzeciw, jakie mogą budzić, ile z powodu przemyśleń, do których inspirują ${ }^{3}$. Celem niniejszej pracy jest próba podsycenia tej inspiracji.

\section{II}

Twierdzenia o pozytywnych związkach (korelacjach) między prawem antymonopolowym a demokracją można dowodzić choćby za pomocą następującego prostego rozumowania: 1. konkurencja (rynkowa) jest warunkiem sine qua non demokracji; 2. prawo antymonopolowe służy ochronie tej konkurencji; 3. prawo antymonopolowe sprzyja więc demokracji. Poprawność tego wnioskowania i wiarygodność konkluzji warunkuje jednak prawdziwość jego przesłanek. Pierwsza z nich wydaje się niesporna zarówno z teoretycznego, jak i empirycznego punktu widzenia.

Po pierwsze, konkurencja w czterech jej wymiarach: 1. ekonomicznym, kojarzonym z rynkiem (konkurencja towarów i usług); 2. politycznym, utożsamianym $\mathrm{z}$ demokracją par excellence (konkurencja programów politycznych, której egzemplifikacją są wybory); 3. kulturowym, wiązanym z pluralizmem (konkurencja idei, której wyrazem jest wolność słowa), oraz 4. prawnym, kojarzonym między innymi z instytucją kontradyktoryjnych postępowań sądowych (konkurencja argumentów prawnych), stanowi fundament demokratycznego społeczeństwa ${ }^{4}$. Wszystkie cztery wymiary konkurencji (ekonomiczny, polityczny, kulturowy i prawny) są przy tym równie ważne dla zdrowej demokracji i żaden z nich nie powinien być uzasadniany wyłącznie kryteriami efektywnościowymi ${ }^{5}$. Według W. Euckena (głównego teoretyka ordoliberalizmu) występowanie w gospodarce ładu konkurencyjnego uniemożliwia niejako ex definitione jednym podmiotom gospodarczym zdobycie pozycji przewagi i sprawowanie władzy wobec innych podmiotów ${ }^{6}$. Jak z kolei

3 Nawiązanie do motta J.K. Galbraitha otwierającego wstęp do opus magnum J.A. Schumpetera, Capitalism, Socialism and Democracy, London 2003, s. IX.

${ }^{4}$ Zob. O. Andriychuk, Thinking inside the box: Why competition as a process is a sui generis right - a methodological observation, [w:] The Goals of Competition Law, red. D. Zimmer, Cheltenham 2012, s. 103 n.; idem, Rediscovering the spirit of competition: On the normative value of the competitive process, „European Competition Journal” 6, 2010, nr 3, s. 599.

5 O. Andriychuk, Rediscovering the spirit..., s. 590.

6 P. Pysz, Społeczna gospodarka rynkowa. Ordoliberalna koncepcja polityki gospodarczej, Warszawa 2008, s. 66. 
twierdził M. Friedman, system gospodarczy, który bezpośrednio zapewnia wolność ekonomiczną, to znaczy kapitalizm wolnokonkurencyjny, rozwija również wolność polityczną, ponieważ oddziela władzę gospodarczą od politycznej, a co za tym idzie - je równoważy ${ }^{7}$. Szczególnie wymowna jest jednak konstatacja Euckena, iż

dobrze funkcjonujący ustrój oparty na konkurencji nie jest w stanie obronić człowieka przed ekonomicznym niedostatkiem. Ale tylko on chroni przed niebezpieczeństwem totalitaryzmu ${ }^{8}$.

Po drugie, fakty historyczne dotyczące związków między konkurencją, która jest kwintesencją wolnego rynku (także w wariancie społecznej gospodarki rynkowej), a demokracją, której podstawowym filarem jest wolność polityczna, są jednoznaczne. Jak pisał przytaczany już Friedman:

nie znam żadnego przykładu społeczeństwa odznaczającego się dużym stopniem swobody politycznej, w którym znakomita część gospodarki nie funkcjonowałaby na zasadach wolnorynkowych ${ }^{9}$.

Nawiasem mówiąc (czego dowodzi też historia), kapitalizm (ergo konkurencja) jest warunkiem koniecznym do zaistnienia wolności politycznej (ergo demokracji), bez wątpienia jednak nie jest to warunek wystarczający ${ }^{10}$. Podsumowując, można przyjąć, że konkurencja jest wartością wpisującą się w aksjologię demokratycznego państwa prawa i społeczeństwa obywatelskiego opartego na poszanowaniu wolności i godności człowieka ${ }^{11}$.

Znacznie bardziej dyskusyjna jest teza, iż prawo antymonopolowe służy ochronie konkurencji, a tym bardziej, że bez niego konkurencja nie może się ostać. Co prawda istnieją poglądy kwestionujące (z różnym nasileniem) ratio legis tej dziedziny prawa, opowiadające się za jej całkowitą abolicją, a przynajmniej drastyczną redukcją jej roli (do grona najbardziej reprezentatywnych głosicieli tych poglądów należą przedstawiciele tak zwanej austriackiej szkoły ekonomii oraz zwolennicy teorii wyboru publicznego, w tym jej odłamu zwanego szkołą chicagowską, czy też ekonomicznej analizy prawa), niemniej jednak idea, że najlepszym rozwiązaniem jest nietworzenie prawa antymonopolowego, nie wytrzymuje konfrontacji z realiami ${ }^{12}$. Te (zarówno historyczne, jak i współczesne) dostarczają bowiem aż nadto dowodów potwierdzających tezę Euckena, że ustrój gospodarczy

7 M. Friedman, Kapitalizm i wolność, przeł. B. Sałbut, Warszawa 1993, s. 22.

8 W. Eucken, Podstawy polityki gospodarczej, red. E. Eucken, K.P. Hensel, przeł. J. Kałążny, Poznań 2005, s. 358.

9 M. Friedman, op. cit., s. 40-41.

10 Ibidem, s. 41.

11 R. Molski, Konkurencja jako element spolecznej gospodarki rynkowej, [w:] Wokół konstytucji i zdrowego rozsadku. Circum constitutionem rationemque sanam. Prace dedykowane Profesorowi Tadeuszowi Smolińskiemu, red. J. Ciapała, A. Rost, Szczecin-Jarocin 2011, s. 162 n.

12 Zob. R. Molski, Prawo antymonopolowe w obliczu globalizacji. Kierunki rozwoju, Bydgoszcz-Szczecin 2007, s. 74 n. 
oparty na konkurencji w żadnym razie nie jest ładem naturalnym (ordre naturel), ponieważ nieustannie zagrażają mu silne grupy interesów, chcące — jak to ujmował W. Lippmann - uwolnić się spod „,bezlitosnej dyktatury rynku”13. Dlatego też - z powodu immanentnej skłonności konkurencji do autodestrukcji (paradoks konkurencji), która sama w sobie (nieograniczona, niekontrolowana i przede wszystkim niechroniona przez państwo) ulega samoograniczaniu, czego przejawem jest choćby postępująca oligopolizacja czy nawet monopolizacja rynków ${ }^{14}$ — konkurencja ta wymaga ochrony prawnej.

W przeświadczeniu o szczególnie doniosłej roli, jaką ma w tym względzie do odegrania prawo antymonopolowe, Eucken zaliczał je do zasad regulujących prawidłowe funkcjonowanie ustroju gospodarczego ${ }^{15}$, a L. Erhard traktował to prawo jako nieodłączny element społecznej gospodarki rynkowej ${ }^{16}$. Podobne stanowisko odnajdziemy w poglądach polskiej doktryny i orzecznictwa sądowego. Przykładowo A. Chełmoński do przejawów wyodrębnionej w obrębie swoistych zasad publicznego prawa gospodarczego zasady ochrony prawidłowego funkcjonowania społecznej gospodarki rynkowej zaliczył między innymi właśnie ochronę konkurencji, postrzegając ją jako istotną i trwałą wartość gospodarczą, której dochowanie jest powinnością państwa ${ }^{17}$. Z kolei w jednym z orzeczeń Sądu Najwyższego podkreślono, że

w dotychczasowej linii orzecznictwa nie było sporne, iż w interesie publicznym jest podejmowanie ochrony zasad swobodnej konkurencji — mechanizmu konkurencji — jako optymalnego sposobu podziału dóbr w społecznej gospodarce rynkowej ${ }^{18}$.

13 W. Eucken, op. cit., s. 73 n.; W. Lippmann, The Good Society, New York 2017, s. 168 n. Notabene już znacznie wcześniej Adam Smith zauważał, że ,rzadko się zdarza, by spotkanie ludzi tego samego zawodu, nawet tylko dla zabawy czy rozrywki, kończyło się inaczej, jak zmową przeciw ogółowi lub jakimś układem co do podniesienia cen" (idem, Badania nad natura i przyczynami bogactwa narodów, t. 1, przeł. G. Wolff, O. Einfeld, Z. Sadowski, Warszawa 1954, s. 169), a P.J. Proudhon ostrzegał, że „konkurencja zabija konkurencję” (idem, The Philosophy of Poverty: The System of Economic Contradictions, Auckland 2012, s. 235).

14 W. Eucken, op. cit., s. 73 n.

15 Ibidem, s. $331 \mathrm{n}$.

16 L. Erhard, Prosperity through Competition, New York 1958, s. 2-3; zob. też D.J. Gerber, Law and Competition in Twentieth Century Europe: Protecting Prometheus, Oxford 2001, s. 266 n.

17 A. Chełmoński, Zasady publicznego prawa gospodarczego, [w:] Zasady prawa gospodarczego. Materiaty konferencyjne, red. A. Śmieja, Wrocław 1999, s. 50-51; zob. też L. Kieres, Społeczna gospodarka rynkowa w orzecznictwie Trybunatu Konstytucyjnego, [w:] Przedsiębiorca w społecznej gospodarce rynkowej, red. T. Kocowski, J. Gola, „Prace Naukowe Uniwersytetu Ekonomicznego we Wrocławiu" 2014, nr 372, s. 188; K. Kiczka, Europeizacja społecznej gospodarki rynkowej w Polsce, [w:] Przedsiębiorca w społecznej..., s. 162-163; C. Banasiński, Dyskrecjonalność w prawie antymonopolowym, Warszawa 2015, s. $15 \mathrm{n}$.

18 Wyrok Sądu Najwyższego z dnia 7 stycznia 2010 r., III SK 16/08, OSNP 2010, nr 13-14, poz. 177. 
Efektywna konkurencja, przynajmniej w pożądanym kształcie, nie może zatem się obyć bez prawa antymonopolowego, opartego na przymusie państwowym, podobnie jak wolność osoby nie może istnieć bez popartych przymusem państwa przepisów prawa, które chronią tę wolność przed nadużyciami innych osób. W konsekwencji, jak to dobitnie wyraził Eucken:

w pejzażu nowoczesnego państwa przemysłowego musi się pojawić ta ogromna, centralna postać urzędu antymonopolowego. Bez niej bowiem ustrój oparty na konkurencji, a wraz z nim nowoczesne państwo prawne, są zagrożone. Urząd antymonopolowy jest tak samo potrzebny jak sąd najwyższy ${ }^{19}$.

Przechodząc do bezpośrednich związków prawa antymonopolowego i demokracji, należy odnotować, że mimo stricte ekonomicznej (proefektywnościowej) ortodoksji, którą naznaczone jest obecnie to prawo (w imię maksymalizacji swoiście pojmowanego dobrobytu konsumentów ${ }^{20}$, w większości, jeśli nie wszystkich jurysdykcjach mających prawny system ochrony konkurencji prawo antymonopolowe postrzegane bywa nie tylko jako ważny element porządku gospodarczego, lecz także jako odpowiedź na istotne problemy demokracji. Problemy, których źródłem może być wykorzystywanie prywatnej władzy nie tylko w celu naruszania wolności innych podmiotów prywatnych, ale też wpływania na decyzje publiczne wrażliwe na tego rodzaju władzę ${ }^{21}$ (jak wiadomo, władza gospodarcza łatwo przekłada się na władzę polityczną).

Od zarania dziejów współczesnego prawa antymonopolowego promowanie i ochrona demokracji były uznawane za jeden z jego celów ${ }^{22}$. Pionierska ustawa Shermana była inspirowana nie tylko (czy nawet nie tyle) dążeniem do gospodarczej efektywności, lecz także (a raczej przede wszystkim) walką z trustami. Co wielce wymowne, Sąd Najwyższy USA zwykł opisywać tę ustawę jako Kartę wolności o wymiarze niemal konstytucyjnym. W Stanach Zjednoczonych uznaje się ją (a ogólniej - całe prawo antytrustowe) za tak samo istotne dla zachowania wolności gospodarczej i systemu wolnorynkowego, jak Karta wolności jest ważna dla ochrony fundamentalnych wolności osobistych w tym kraju ${ }^{23}$. Także w większości innych krajów implementowano prawo antymonopolowe z myślą o promocji nie tylko gospodarczej efektywności, ale też takich wartości demokratycznych, jak wolność gospodarcza, separacja władzy gospodarczej (prywatnej) i politycznej (publicznej) czy pluralizm w gospodarce.

Przykładowo przekonanie, że skartelizowane i zdominowane przez wielkie koncerny gospodarki Niemiec i Japonii w okresie poprzedzającym wybuch

19 W. Eucken, op. cit., s. 334.

20 O kontrowersjach towarzyszących temu kryterium zob. B.Y. Orbach, The antitrust consumer welfare paradox, „Journal of Competition Law \& Economics” 7, 2010, nr 1, s. 133 n.

21 G. Amato, op. cit., s. 2.

22 S.W. Waller, Competition and Democracy, OECD 2017, s. 4.

23 Zob. wyrok SN USA w sprawie United States v. Topco Assoc. Inc., 405 U.S. 596, 610 (1972). 
II wojny światowej wydatnie przyczyniły się do rozwoju militaryzmu w tych krajach, a w konsekwencji - wybuchu wojny ${ }^{24}$, doprowadziło do wprowadzenia tam (skądinąd pod presją władz amerykańskich) reżimu antymonopolowego, który miał zabezpieczać przed powrotem praktyk monopolistycznych w gospodarce i totalitarnych rządów (wpływ na niemieckie prawo antymonopolowe miały również idee ordoliberalnej szkoły fryburskiej, która też podkreślała potrzebę rozdzielenia władzy politycznej i gospodarczej w celu zapobieżenia wspomnianym zagrożeniom) ${ }^{25}$. Z kolei prawo konkurencji Unii Europejskiej ma zarówno promować efektywną produkcję, jak i służyć realizacji szerszego spektrum celów traktatów unijnych, które dalece wykraczają poza kwestie gospodarcze. Wśród tych celów mieści się ochrona pluralistycznej demokracji, która nie przetrwałaby silnej koncentracji władzy gospodarczej ${ }^{26}$. Patrząc z jeszcze szerszej (globalnej) perspektywy, należy odnotować, że ekspansja prawa antymonopolowego w wielu krajach przechodzących transformację systemową po upadku Związku Radzieckiego w wyrazisty sposób manifestuje ważność wolności ekonomicznych odzwierciedlanych w tym prawie ${ }^{27}$. W Polsce jednym z symboli przekształcania gospodarki nakazowo-rozdzielczej w nowoczesną gospodarkę rynkową, towarzyszącego przemianom demokratycznym, była ustawa z dnia 24 lutego 1990 roku o przeciwdziałaniu praktykom monopolistycznym ${ }^{28}$.

Pozytywne oddziaływanie prawa antymonopolowego na demokrację może przejawiać się na wiele sposobów i w rozmaitych kontekstach. Bodaj najważniejsze jest tłumienie nadmiernej koncentracji gospodarczej, co zasadza się na idei, że korporacje gospodarcze nie powinny dysponować większą władzą i wpływami niż wybrane demokratycznie władze publiczne. Już w czasach antycznych dostrzegano, że demokracja funkcjonuje lepiej, gdy władza polityczna i gospodarcza jest rozproszona. Jak pisał Arystoteles:

wspólnota państwowa, która na średnim stanie się opiera, jest najlepsza [...], takie państwa mogą posiadać dobry ustrój, w których istnieje liczny stan średni, silniejszy bezwzględnie od obu pozostałych lub jeśli nie, to chociażby od jednego z nich. Bo na którąkolwiek stronę się skłoni, przechyla szalę i nie dopuszcza do wytworzenia przewagi jednej czy drugiej skrajności ${ }^{29}$.

${ }^{24}$ Zob. J.O. Haley, Antitrust in Germany and Japan: The First Fifty Years, 1947-1998, Seattle 2001.

25 Zob. D.J. Gerber, op. cit., s. 232 n.; idem, Constitutionalizing the economy: German neo-liberalism, comparative law and the new Europe, „The American Journal of Comparative Law” 42, 1994, s. 25 n.

26 K. Van Miert, A pragmatic approach to Europe's competition policy, „Frontier-free Europe” 5 kwietnia 1993.

27 Zob. S.W. Waller, op. cit., s. 7; idem, Neo-realism and the international harmonization of law: Lessons from antitrust, „Kansas Law Review” 42, 1994, s. 582 n.

28 Dz.U. Nr 14, poz. 88 ze zm.

29 Arystoteles, Polityka, przeł. L. Piotrowicz, [w:] idem, Dzieła wszystkie, t. 1, Warszawa 2003, s. 99. 
Egzemplifikacją poglądu, iż koncentracja władzy gospodarczej w rękach jednego bądź niewielkiej grupy podmiotów stwarza zagrożenie dla demokratycznego państwa, jest wypowiedź F.D. Roosevelta:

wolność demokracji jest zagrożona, gdy naród toleruje wzrost władzy prywatnej do takiego stopnia, że władza ta staje się silniejsza od władzy demokratycznego państwa ${ }^{30}$.

Nawiasem mówiąc, wypowiedź ta zawiera też inną (pomijaną zwykle) przestrogę:

wolność demokracji jest zagrożona, gdy jej system gospodarczy nie zapewnia pracy ani też nie wytwarza i nie dzieli dóbr w sposób zapewniający akceptowalny poziom życia ${ }^{31}$.

Do podobnej konstatacji prowadzi wykładnia art. 30 Konstytucji RP ${ }^{32}$, stanowiącego o nienaruszalnej, przyrodzonej i niezbywalnej godności człowieka, której poszanowanie i ochrona jest powinnością władz publicznych. Nie ulega wątpliwości, że przesłanką poszanowania godności człowieka jest między innymi istnienie pewnego minimum materialnego, zapewniającego jednostce możliwość samodzielnego funkcjonowania w społeczeństwie oraz stworzenie każdemu człowiekowi szans na pełny rozwój osobowości w otaczającym go środowisku kulturowym i cywilizacyjnym ${ }^{33}$. W społecznej gospodarce rynkowej, na której zgodnie z art. 20 Konstytucji RP oparty jest ustrój gospodarczy RP, zapewnienie godziwego bytu zależy między innymi od skutecznej ochrony konkurencji przez prawo antymonopolowe ${ }^{34}$.

Sugestywne stanowisko w kwestii zagrożeń wynikających z nadmiernej koncentracji władzy gospodarczej odnajdziemy również w orzecznictwie Sądu Najwyższego USA, który formułując tezy dotyczące filozoficznych uzasadnień ustawy Shermana, podkreślał, że: 1. władza kontrolowania gospodarki powinna pozostawać w rękach wybranych przedstawicieli narodu, a nie przemysłowej oligarchii; 2. władza gospodarcza powinna być rozproszona, tak aby losy narodu nie zależały od życzeń czy wręcz kaprysów, uprzedzeń politycznych czy równowagi emocjonalnej kilku samozwańczych ludzi (okoliczność, że mogą oni cieszyć się

30 F.D. Roosevelt, Message to Congress on curbing monopolies, 29 kwietnia 1938, http://www. presidency.ucsb.edu/ws/?pid=15637 (dostęp: 18.12.2017).

31 Ibidem.

32 Dz.U. Nr 78, poz. 483 ze zm.

33 Zob. wyrok Trybunału Konstytucyjnego z dnia 4 kwietnia 2001 r., K. 11/00, OTK ZU 2001, nr 3, poz. 54; M. Granat, Godność człowieka z art. 30 Konstytucji RP jako wartość i jako norma prawna, „Państwo i Prawo” 2014, z. 8, s. 3 n.

34 B. Zdziennicki, Znaczenie publicznoprawnej ochrony konkurencji dla praw jednostki, [w:] Wokót wybranych problemów konstytucjonalizmu. Księga jubileuszowa Profesora Andrzeja Batabana, red. J. Ciapała, P. Mijal, Warszawa 2017, s. 354. 
społecznym zaufaniem i szacunkiem, jest w tym względzie bez znaczenia) ${ }^{35}$. Także w doktrynie prawa antymonopolowego niejednokrotnie przestrzegano przed taką wykładnią tego prawa, która w trudnych czasach czyniłaby je niezdolnym do pełnienia funkcji instrumentu ochrony przed niepożądaną koncentracją władzy gospodarczej ${ }^{36}$. Uprzedzano przy tym, że jeśli pozwoli się na rozwój wolnorynkowej gospodarki w warunkach prawa antymonopolowego ignorującego wszystko, co nie ma wymiaru ekonomicznego, prawdopodobnym rezultatem takiej polityki będzie zdominowanie rynku przez kilka gospodarczych Behemotów wymuszających na państwie odgrywanie bardziej ingerencyjnej roli w gospodarce ${ }^{37}$.

W powszechnym przekonaniu prawo antymonopolowe może promować demokrację także dzięki temu, że przyczynia się do bardziej sprawiedliwej dystrybucji dochodów, a tym samym obniżania nierówności społecznych, zwłaszcza przeciwdziałając (w imię ochrony konsumentów i mniejszych przedsiębiorców) cenowym praktykom kartelowym oraz nadużyciom pozycji dominującej (monopolizacji rynku) $)^{38}$. Ten sprawiedliwościowy efekt prawa antymonopolowego ma, co prawda, wyraźnie bardziej pozytywny wpływ na poziom demokracji w porównaniu ze skutkiem proefektywnościowym (to jest wzrostem dochodów towarzyszącym rozwojowi gospodarczemu), jednak — jak się powszechnie uznaje — nie jest on znaczący (notabene istnieje wiele bardziej skutecznych instrumentów polityki redystrybucyjnej, jak na przykład progresywne opodatkowanie czy bezpośrednie transfery finansowe $)^{39}$.

Z pewnością umacnianiu demokracji sprzyja antykorupcyjny charakter prawa antymonopolowego. Szczególnie użyteczne w walce z korupcją mogą być interwencje antymonopolowe służące przeciwdziałaniu zmowom (kartelom) przetargowym oraz przekupstwu w sektorze zamówień publicznych (jak wiadomo, przestępcza aktywność tego rodzaju podważa nie tylko proces konkurencji, lecz także instytucje wspierające systemy demokratyczne) ${ }^{40}$.

Prawo antymonopolowe może również (a zdaniem wielu nawet powinno) chronić i promować wolność słowa ${ }^{41}$, będącą jedną z najważniejszych gwarancji

35 Zob. wyrok SN USA w sprawie United States v. Columbia Steel Co., 334 U.S. 495, 536 (1948).

36 R. Pitofsky, The political content of antitrust, „University of Pennsylvania Law Review” 127, 1979, s. 1058.

37 Ibidem, s. 1051.

38 T.C. Ma, Antitrust and democracy: Perspectives from efficiency and equity, „Journal of Competition Law \& Economics" 12, 2016, nr 2, s. 235 n.

39 Ibidem. Podobnie N. Petersen, Antitrust law and the promotion of democracy and economic growth, „Journal of Competition Law \& Economics” 9, 2013, nr 3, s. 593 n.

40 Zob. Fighting Corruption and Promoting Competition, OECD 2014; Recommendation of the OECD Council on Fighting Bid Rigging in Public Procurement, OECD 2012.

41 Zob. np. J. Drexl, Competition law in media markets and its contribution to democracy - a global perspective, „Max Planck Institute for Innovation and Competition Research Paper” nr 14-16, s. 2 n. 
demokratycznego państwa, w którym funkcjonuje zasada rządów prawa (B. Cardozo wolność tę określił jako fundamentalny i niezbywalny warunek istnienia jakiejkolwiek innej formy wolności) ${ }^{42}$. Ten nieobcy prawu antymonopolowemu cel o charakterze politycznym, będący elementem demokratycznej konstytucji i kultury demokracji, jest szczególnie istotny w krajach rozwijających się i przechodzących transformację ustrojową, których dążenia nie sprowadzają się tylko do dobrobytu gospodarczego, lecz także obejmują rozwój trwałych społeczeństw obywatelskich i demokratycznych struktur ${ }^{43}$. W sposób najbardziej jaskrawy prodemokratycznie motywowane interwencje antymonopolowe na rzecz wolności słowa przejawiają się w obszarze kontroli koncentracji na rynkach mediów, co jest zrozumiałe, zważywszy na ich newralgiczny politycznie charakter (nieprzypadkowo media zwie się czwartą władzą) i wpływ takich transakcji na pluralizm i różnorodność środków masowego przekazu, sprzyjające wolności wypowiedzi (określona skala koncentracji kapitału w sektorze mediów może stać się zagrożeniem dla wolności słowa) ${ }^{44}$.

Pozytywne korelacje między prawem antymonopolowym a demokracją nie mają jednak charakteru jednokierunkowego. Nie tylko, jak wykazano, prawo antymonopolowe ma rzeczywiście lub potencjalnie pozytywny wpływ na demokrację, lecz także demokracja sprzyja temu prawu, i to co najmniej dwojako. Po pierwsze, ustroje demokratyczne z natury rzeczy są bardziej predestynowane do implementacji prawa antymonopolowego w porównaniu z ustrojami niedemokratycznymi, w których konkurencja rynkowa niejednokrotnie nie ma racji bytu bądź też nie odgrywa roli podstawowego mechanizmu koordynacji procesów gospodarczych. Zależność ta nie jest jednak oczywista, co ilustruje na przykład paradoksalny fakt, że kompleksowe prawo antymonopolowe wdrożono wcześniej w komunistycznych Chinach (2008) niż w kapitalistycznym Hongkongu (2015) ${ }^{45}$. Po drugie, ponad wszelką wątpliwość realny, dobrze funkcjonujący ustrój demokratyczny sprzyja prawidłowej realizacji misji prawnej ochrony konkurencji, a wręcz jest warunkiem sine qua non sprawiedliwego i efektywnego prawa antymonopolowego. Dysfunkcjonalna czy też fasadowa demokracja (nie mówiąc już o ustroju jawnie autorytarnym) może co prawda implementować prawo antymonopolowe, ale za sprawą

42 Zob. P. Laidler, Konstytucja Stanów Zjednoczonych. Przewodnik, Kraków 2007, s. 112; szerzej zob. A. Wiśniewski, Znaczenie wolności słowa w państwie demokratycznym, „Gdańskie Studia Prawnicze" 2000, nr 7, s. 645 n.

43 J. Drexl, op. cit., s. 2, 30.

44 Ibidem, s. 14 n.; zob. też T. Skoczny, Zgody szczególne w prawie kontroli koncentracji, Warszawa 2012, s. 217 n.; J. Skrzypczak, Regulacje prawne dotyczace koncentracji kapitału w przedsiębiorstwach medialnych w wybranych krajach Unii Europejskiej, ,Internetowy Kwartalnik Antymonopolowy i Regulacyjny" 2017, nr 7 (6), s. 87 n.; H.A. Shelanski, Antitrust law as mass media regulation: Can merger standards protect the public interest?, „California Law Review” 94, 2002, s. $371 \mathrm{n}$.

45 Zob. M. Gu, Antitrust Law and Practice in China and Hong Kong, Hong Kong 2016; M. Williams, Competition Policy and Law in China, Hong Kong and Taiwan, Cambridge 2005. 
nieuniknionych słabości w systemie praworządności prawo to i praktyka jego stosowania nieuchronnie okażą się suboptymalne ${ }^{46}$. W tym kontekście, notabene, nie powinno dziwić, że chińskie prawo antymonopolowe zyskało metaforyczne miano „bezzębnego tygrysa”, ${ }^{\natural 7}$.

W świetle poczynionych uwag uprawniona wydaje się konstatacja, że między prawem antymonopolowym a demokracją istnieje wyraźna symbioza (jeśli nie synergia).

Prawo antymonopolowe jest istotnym gwarantem otwartych i konkurencyjnych rynków, które z kolei są niezbędnym fundamentem demokracji. Chroniona przez to prawo konkurencja jest nie tylko podstawą demokracji, lecz także barometrem wskazującym, jak solidne są jej fundamenty. Transparentny, przewidywalny i efektywny system ochrony konkurencji odzwierciedla poszanowanie dla fundamentalnych praw i wolności człowieka, co znamionuje ustroje demokratyczne.

$\mathrm{Z}$ jednej strony prawo antymonopolowe nie powinno ograniczać się wyłącznie do promowania wzrostu gospodarczego i efektywności gospodarczej. Ma ono też do odegrania nie mniej ważką rolę instrumentu ochrony podstawowych wartości demokratycznego społeczeństwa przed zagrożeniami, jakie wiążą się $\mathrm{z}$ defektami wolnego rynku. Z drugiej zaś - to demokratyczne zasady, instytucje i procedury chronią przed przerodzeniem się tego instrumentu w narzędzie publicznej opresji. A trzeba mieć świadomość, że skutki takiego nadużycia mogłyby być nader dotkliwe, zwłaszcza że prawo antymonopolowe to bardziej młot niż skalpel $^{48}$.

\section{ON THE SYMBIOSIS OF ANTITRUST LAW AND DEMOCRACY}

\section{Summary}

Multifaceted and multidirectional relationships between antitrust law and democracy are often complex and ambivalent. Some of them are of positive nature (positive correlations) and the others - negative (contradictions). Those of the former, which absorb particular attention of law and state theoreticians and practitioners, are the subject of the presented paper. Its aim is to stimu-

46 M. Williams, op. cit., s. 433.

47 Zob. np. C. Wu, Z. Liu, A tiger without teeth? Regulation of administrative monopoly under China's anti-monopoly law, „Review of Industrial Organization” 41, 2012, s. 144.

48 Tym obrazowym skojarzeniem posłużyli się R.A. Cass i K.N. Hylton w artykule Preserving competition: Economic analysis, legal standards and Microsoft, „George Mason Law Review” 8, 1999, s. 1. 
late reflections on the title question rather than provoking agreement or disagreement. However, in the author's view, there are ample arguments that support the main conclusion of the survey, namely: that antitrust law and democracy clearly coexist in symbiosis (if not synergy).

Keywords: antitrust law, democracy, positive correlations

\section{BIBLIOGRAFIA}

Amato G., Antitrust Law and the Bounds of Power: The Dilemma of Liberal Democracy in the History of the Market, Oxford 1997.

Andriychuk O., Rediscovering the spirit of competition: On the normative value of the competitive process, „European Competition Journal” 6, 2010, nr 3.

Andriychuk O., Thinking inside the box: Why competition as a process is a sui generis right a methodological observation, [w:] The Goals of Competition Law, red. D. Zimmer, Cheltenham 2012.

Arystoteles, Polityka, przeł. L. Piotrowicz, [w:] idem, Dzieła wszystkie, t. 1, Warszawa 2003.

Banasiński C., Dyskrecjonalność w prawie antymonopolowym, Warszawa 2015.

Cass R.A., Hylton K.N., Preserving competition: Economic analysis, legal standards and Microsoft, „George Mason Law Review” 8, 1999.

Chełmoński A., Zasady publicznego prawa gospodarczego, [w:] Zasady prawa gospodarczego. Materiaty konferencyjne, red. A. Śmieja, Wrocław 1999.

Drexl J., Competition law in media markets and its contribution to democracy - a global perspective, „Max Planck Institute for Innovation and Competition Research Paper” nr 14-16.

Erhard L., Prosperity through Competition, New York 1958.

Eucken W., Podstawy polityki gospodarczej, red. E. Eucken, K.P. Hensel, przeł. J. Kałążny, Poznań 2005.

Friedman M., Kapitalizm i wolnośćc, przeł. B. Sałbut, Warszawa 1993.

Gerber D.J., Constitutionalizing the economy: German neo-liberalism, comparative law and the new Europe, „The American Journal of Comparative Law” 42, 1994.

Gerber D.J., Law and Competition in Twentieth Century Europe: Protecting Prometheus, Oxford 2001.

Granat M., Godność człowieka z art. 30 Konstytucji RP jako wartość i jako norma prawna, „Państwo i Prawo" 2014, z. 8.

Gu M., Antitrust Law and Practice in China and Hong Kong, Hong Kong 2016.

Haley J.O., Antitrust in Germany and Japan: The First Fifty Years, 1947-1998, Seattle 2001.

Kiczka K., Europeizacja społecznej gospodarki rynkowej w Polsce, [w:] Przedsiębiorca w społecznej gospodarce rynkowej, red. T. Kocowski, J. Gola, „Prace Naukowe Uniwersytetu Ekonomicznego we Wrocławiu" 2014, nr 372.

Kieres L., Społeczna gospodarka rynkowa w orzecznictwie Trybunału Konstytucyjnego, [w:] Przedsiębiorca w społecznej gospodarce rynkowej, red. T. Kocowski, J. Gola, „Prace Naukowe Uniwersytetu Ekonomicznego we Wrocławiu" 2014, nr 372.

Laidler P., Konstytucja Stanów Zjednoczonych. Przewodnik, Kraków 2007.

Ma T.C., Antitrust and democracy: Perspectives from efficiency and equity, ,Journal of Competition Law \& Economics" 12, 2016, nr 2.

Molski R., Konkurencja jako element społecznej gospodarki rynkowej, [w:] Wokół konstytucji $i$ zdrowego rozsądku. Circum constitutionem rationemque sanam. Prace dedykowane Profesorowi Tadeuszowi Smolińskiemu, red. J. Ciapała, A. Rost, Szczecin-Jarocin 2011. 
Molski R., Prawo antymonopolowe w obliczu globalizacji. Kierunki rozwoju, Bydgoszcz-Szczecin 2007.

Orbach B.Y., The antitrust consumer welfare paradox, „Journal of Competition Law \& Economics” 7, 2010, nr 1.

Petersen N., Antitrust law and the promotion of democracy and economic growth, „Journal of Competition Law \& Economics" 9, 2013, nr 3.

Pitofsky R., The political content of antitrust, „University of Pennsylvania Law Review” 127, 1979.

Prakkal R., Laine E.E., Capitalism, antitrust, and democracy: Perfect partners or strange bedfellows?, „The Antitrust Bulletin” 61, 2016, nr 2.

Proudhon P.J., The Philosophy of Poverty: The System of Economic Contradictions, Auckland 2012.

Pysz P., Społeczna gospodarka rynkowa. Ordoliberalna koncepcja polityki gospodarczej, Warszawa 2008.

Schumpeter J.A., Capitalism, Socialism and Democracy, London 2003.

Shelanski H.A., Antitrust law as mass media regulation: Can merger standards protect the public interest?, „California Law Review” 94, 2002.

Skoczny T., Zgody szczególne w prawie kontroli koncentracji, Warszawa 2012.

Skrzypczak J., Regulacje prawne dotyczace koncentracji kapitału w przedsiębiorstwach medialnych w wybranych krajach Unii Europejskiej, „Internetowy Kwartalnik Antymonopolowy i Regulacyjny" 2017, nr 7 (6).

Smith A., Badania nad natura i przyczynami bogactwa narodów, t. 1, przeł. G. Wolff, O. Einfeld, Z. Sadowski, Warszawa 1954.

Van Miert K., A pragmatic approach to Europe's competition policy, „Frontier-free Europe” 5 kwietnia 1993.

Waller S.W., Neo-realism and the international harmonization of law: Lessons from antitrust, „Kansas Law Review” 42, 1994.

Waller S.W., Competition and Democracy, OECD 2017.

Williams M., Competition Policy and Law in China, Hong Kong and Taiwan, Cambridge 2005.

Wiśniewski A., Znaczenie wolności słowa w państwie demokratycznym, „Gdańskie Studia Prawnicze" 2000, nr 7.

Wu C., Liu Z., A tiger without teeth? Regulation of administrative monopoly under China's anti-monopoly law, „Review of Industrial Organization” 41, 2012.

Zdziennicki B., Znaczenie publicznoprawnej ochrony konkurencji dla praw jednostki, [w:] Wokót wybranych problemów konstytucjonalizmu. Księga jubileuszowa Profesora Andrzeja Bałabana, red. J. Ciapała, P. Mijal, Warszawa 2017. 